\title{
Effects of number of frozen-thawed ram sperm and number of inseminations on fertility in synchronized ewes under field condition
}

\author{
Pankaj Kumar Jha ${ }^{1,2, *}$, Md. Golam Shahi Alam ${ }^{1}$, Md. Abdullah Al Mansur ${ }^{1}$, \\ Mohammad Rafiqul Islam Talukder ${ }^{1}$, Nazmun Naher ${ }^{1}$, A. K. M. Anisur Rahman ${ }^{3}$, David C. Hall ${ }^{4}$ \\ and Farida Yeasmin Bari ${ }^{1}$ \\ ${ }^{1}$ Department of Surgery and Obstetrics, Bangladesh Agricultural University, Mymensingh-2202, Bangladesh \\ ${ }^{2}$ Nepal Agricultural Research Council (NARC), Khumaltar, Lalitpur-44703, Nepal \\ ${ }^{3}$ Department of Medicine, Bangladesh Agricultural University, Mymensingh-2202, Bangladesh \\ ${ }^{4}$ Department of Ecosystem and Public Health, University of Calgary, Calgary-T2N 4Z6, Canada
}

Received April 13, 2020

Revised May 11, 2020

Accepted June 9, 2020

\section{*Correspondence}

Pankaj Kumar Jha

E-mail: drpankaj.np@gmail.com

ORCID

https://orcid.org/0000-0001-6374-9201

\begin{abstract}
The effects of the number of frozen-thawed ram sperm per single and double intra-cervical artificial insemination (AI) on fertility in ewes were studied. A total of 89 non-pregnant ewes were synchronized for oestrus with two doses of 100 $\mu g$ PGF $_{2 \alpha}$ (Cloprostenol) 9 days apart. The ewes were randomly assigned to one of four groups; D200 ( $n=23$; double Al with $200 \times 10^{6}$ sperm), S200 ( $n=24$; single Al with $200 \times 10^{6}$ sperm), D100 ( $n=24$; double Al with $100 \times 10^{6}$ sperm) and S100 ( $n=18$; single Al with $100 \times 10^{6}$ sperm). Ewes were inseminated within 12 to $18 \mathrm{~h}$ for single $\mathrm{Al}$ and, within 10 to $12 \mathrm{~h}$ and 16 to $18 \mathrm{~h}$ for double $\mathrm{Al}$ after the onset of oestrus. The onset of oestrus ranged from 28 to $76 \mathrm{~h}(54.33 \pm 1.28 \mathrm{~h})$. The high percentage $(29.2 \%)$ of ewes showed oestrus between 51 to $60 \mathrm{~h}$. The non-return rates were highest in group D200 (56.5\%) and differed significantly ( $p$ < 0.05) from group S100 (11.1\%). No ewes were pregnant in group S100, and the pregnancy rates among the remaining groups did not differ. The mean gestation period was $152.8 \pm 0.5$ days and no difference was observed among the groups. The lambing and multiple birth rates were $100 \%$ in group D200. The single and twin lambing was highest in group D100 (33.3\%) and group D200 (83.3\%), respectively. Only one triplet lambing and the highest lambing size $(2.2 \pm 0.2)$ was recorded in group D200. In conclusion, double Al with $200 \times 10^{6}$ sperm showed comparatively most practical for achieving high pregnancy rates and lambing performances in Bangladeshi ewes under field conditions.
\end{abstract}

Keywords: artificial insemination, frozen ram semen, sheep fertility, sperm number

\section{INTRODUCTION}

Sheep in Bangladesh are non-descript indigenous and small sized, called Wera. The breed probably originated from south-eastern sub-tropical humid region's (Turner,
1983). They are hair-wool type, greyish in appearance with black or white patches. The face, ear and feet are mostly light black. The mature body weight weighing 15$25 \mathrm{~kg}$ (Ewe) and 18-22 kg (Ram). They are capable of biannual lambing with litter size commonly $1-2$, rarely 3 
(Bhuiyan, 2006). Indiscriminate breeding, scarcity of superior rams and lack of scientific breeding program are the major constraints. Now a days, sheep rearing is gaining popularity in Bangladesh. Breeding programs for sheep is the major concern of farmers in Bangladesh which necessitates use of sustainable and locally appropriate reproductive techniques. Artificial insemination (AI) in conjugation with oestrus synchronization is extensively used in sheep industries in developed countries. It is one of the important assisted reproductive techniques (ARTs) to disseminate genetic traits of interest and increase progenies in a short time. Cryopreservation of semen allows more efficient use of superior rams (Menchaca and Rubianes, 2004; Tekin, 2006). Success of AI depends on the quality of semen (Tekin, 2006), oestrus synchronization, the number of sperm and timing of insemination (Hashem et al., 2015). To establish sheep AI program in Bangladesh, different types of extenders, both home-made (egg yolk trisbased) and commercial have been studied for ram semen preservation (Azizunnesa et al., 2014; Rekha et al., 2016a, 2016b). Studies were conducted with different analogues and doses of progesterone and prostaglandin to observe the oestrus response and pregnancy rates using chilled and frozen semen in indigenous ewes (Roy et al., 2014; Zohara et al., 2014; Rekha et al., 2016a, 2016b). However, semen freezing and AI in sheep in Bangladesh is limited to research stations. Acceptable results have been achieved using frozen-thawed semen abroad (Maxwell et al., 1995; Anel et al., 2003; Anel et al., 2006). Different doses of frozen sperm $\left(50,100,200,400,500\right.$, and $\left.800 \times 10^{6} / \mathrm{mL}\right)$ have been used in sheep AI (D'Alessandro et al., 2001; Paulenz et al., 2002; Nordstoga et al., 2009). AI in ewes is normally performed $12-24 \mathrm{~h}$ after the onset of oestrus for single insemination (Nordstoga et al., 2009), or 14-22 h after the onset of oestrus for double insemination (Paulenz et al., 2002). Achieving acceptable pregnancy rates is very important for the uptake of sheep AI services. To best of our knowledge, there are no reports on fertility in Bangladeshi ewes after using cryopreserved ram sperm under field condition in Bangladesh. Therefore, the objective of this study was to evaluate the effects of the number of cryopreserved ram sperm per single and double intracervical artificial insemination on fertility in Bangladeshi ewes.

\section{MATERIALS AND METHODS}

All procedures were approved by the Animal Experimental Ethics Committee, Department of Surgery and Obstetrics, Bangladesh Agricultural University (AEEC/DSOBAU/02/2015) and were carried out from September 2016 to October 2017. The frozen ram semen was produced in the laboratory of DOS, BAU (N 24.73 latitude and E 90.44 longitude), and AI was performed at Trisal Upazilla (Sub-district), Mymensingh (N 24.34 latitude and E 90.23 longitude), Bangladesh. The area is elevated at $9 \mathrm{~m}$ above sea level and receives on average $174 \mathrm{~mm}$ of rainfall with the mean annual minimum and maximum temperatures ranges between 16.46 to $29.13^{\circ} \mathrm{C}$, respectively.

\section{Rams}

The best ten selected indigenous rams ("Wera") based on semen quality evaluation were used as semen donors. The rams were aged 2 to 2.5 years, body weight was 18 to $24 \mathrm{~kg}$, and scrotal circumference was 18 to $22 \mathrm{~cm}$. The volume of semen was $\geq 0.5 \mathrm{~mL}$, colour $\geq 3$ (milky white), mass activity $\geq 4$, motility $\geq 80 \%$, viability $\geq 90 \%$, concentration $\left(10^{6} / \mathrm{mL}\right) \geq 2500$, plasma membrane integrity (HOST) $\geq 85 \%$, acrosome integrity $\geq 90 \%$, and normal sperm $\geq 80 \%$. The rams belonged to a project funded by Bangladesh Academy of Science and United States Department of Agriculture (BAS-USDA; LS-02) and reared at a research farm, DSO, BAU (Jha et al., 2018).

\section{Chemicals}

All chemicals used in this study were from Sigma (St. Louis, MO, USA) and Merck (Darmstadt, Germany).

\section{Semen collection and evaluation}

Briefly, semen was collected using an artificial vagina (Jha et al., 2018). Soon after collection, the tube containing semen was immersed in a water bath at $35^{\circ} \mathrm{C}$. Sperm motility (\%; warming stage at $37^{\circ} \mathrm{C}$ ) was estimated subjectively by placing a drop of semen $5 \mu \mathrm{L}(100 \times)$ using a coverslip. Sperm concentration $\left(10^{6} / \mathrm{mL}\right)$ was calculated using a Neubauer counting chamber at a dilution of 1:200 (semen: buffered formal saline, 200×).

\section{Semen dilution, freezing, and preservation}

A home-made tris based extender (Tris $3.63 \mathrm{~g}$, fructose $0.5 \mathrm{~g}$, citric acid $1.99 \mathrm{~g}$ in $100 \mathrm{~mL}$ of deionized water) was 
prepared and the stock was stored at $5^{\circ} \mathrm{C}$. On the day of semen collection, the final extender was prepared by adding egg-yolk $20 \% \mathrm{v} / \mathrm{v}$, penicillin G (sodium salt) 100,000 IU, dihydrostreptomycin sulfate $100 \mathrm{mg}$ after which the extender was split into two fractions: fraction A (no glycerol) and fraction B ( $5 \% \mathrm{v} / \mathrm{v}$ glycerol).

Only ejaculates with volume $\geq 0.5 \mathrm{~mL}$, sperm motility $\geq 80 \%$, and sperm concentration $\geq 2500 \times 10^{6} / \mathrm{mL}$ were processed. Individual ram semen ejaculates were extended to two final concentrations of 400 and $800 \times$ $10^{6}$ spermatozoa/mL, in two fraction dilution step. Semen was diluted with fraction $\mathrm{A}$ at $+35^{\circ} \mathrm{C}$ and cooling gradually $\left(-0.25^{\circ} \mathrm{C} / \mathrm{min}\right)$ from +35 to $+5^{\circ} \mathrm{C}$ in $120 \mathrm{~min}$. The samples were further diluted with fraction $\mathrm{B}$ at $+5^{\circ} \mathrm{C}$. The diluted semen was loaded into $0.25 \mathrm{~mL}$ French mini straws and were equilibrated at $5^{\circ} \mathrm{C}$ for $120 \mathrm{~min}$. The straws were frozen in liquid nitrogen (LN2) vapor in a Styrofoam box using 3 step freezing technique developed in our laboratory (Jha et al., 2019). The straws were placed $9 \mathrm{~cm}$ above the surface of LN2 for $7.5 \mathrm{~min}$ (where the temperature decreased from $+5^{\circ} \mathrm{C}$ to $-80^{\circ} \mathrm{C}$ at $11.33^{\circ} \mathrm{C} / \mathrm{min}$ ), at $7 \mathrm{~cm}$ for $1.5 \mathrm{~min}$ (from $-80^{\circ} \mathrm{C}$ to $-120^{\circ} \mathrm{C}$ at $26.66^{\circ} \mathrm{C} / \mathrm{min}$ ), and at $5 \mathrm{~cm}$ for $1.5 \mathrm{~min}$ (from $-120^{\circ} \mathrm{C}$ to $-140^{\circ} \mathrm{C}$ at $13.33^{\circ} \mathrm{C} / \mathrm{min}$ ). Finally the straws were plunged into the LN2 $\left(-196^{\circ} \mathrm{C}\right)$.

The semen straws were thawed in warm water at $37^{\circ} \mathrm{C}$ for $20 \mathrm{sec}$. Batches with sperm motility $\geq 50 \%$ were stored in Cryocan for AI purposes.

\section{Ewes for $\mathrm{Al}$ and its management in the field}

An interaction program in consultation with the District Livestock Services (DLS) was organized to acquaint the sheep farmers about the application and benefits of AI. Apparently mature, healthy and non-pregnant ewes ( $\mathrm{n}=$ 89 out of 237) aged $\geq 16$ to 30 month, body weight $\geq 15$ to $18 \mathrm{~kg}$, body condition score $\geq 3.5$ to 4 and parity $\geq$ 1 to 3 were selected with the aid of ultrasound scanning (DRAMINSKI ANIMAL profi portable ultrasound scanner, Poland) using a $5.0 \mathrm{MHz}$ trans-abdominal transducer. To prevent natural mating, the neighboring farmer's ewes were housed separately from the day of ultrasonography to non-return period. Feeding, grazing, watering, and housing remained as routinely done by the farmer.

\section{Experimental design}

The ewes $(n=89)$ were randomly allocated into 4 groups: D200 $\left(\mathrm{n}=23\right.$; double AI with $200 \times 10^{6}$ sperm);
S200 ( $=24$; single AI with $200 \times 10^{6}$ sperm); D100 ( $=$ 24; double AI with $100 \times 10^{6}$ sperm); and $\mathrm{S} 100$ ( $\mathrm{n}=18$; single AI with $100 \times 10^{6}$ sperm). The insemination was performed 12 to $18 \mathrm{~h}$ after the onset of oestrus for single $\mathrm{AI}$, or 10 to $12 \mathrm{~h}$ and 16 to $18 \mathrm{~h}$ after the onset of oestrus for double AI.

\section{Oestrous synchronization}

Oestrous synchronization was done according to Zohara et al. (2014). All ewes were given two doses of $0.4 \mathrm{~mL}$ (100 $\mu \mathrm{g})$ intramuscular $(\mathrm{im})$ prostaglandin $\mathrm{F}_{2 \alpha}\left(\mathrm{PGF}_{2 \alpha}\right)$ analogue (Cloprostenol, Ovuprost, Bayer New Zealand Ltd., Auckland, New Zealand) 9 days apart.

\section{Artificial insemination}

The ewes were positioned upright with their head down and hind quarter up. AI was performed using an eccentric inseminating pipette and insemination gun (Minitube, Slovakia) with the help of vaginal speculum and penlight. The semen was slowly deposited as deep as possible into the cervix. Insemination was performed by the same inseminator through the study.

\section{Reproductive performance}

The onset of oestrous was determined by monitoring every $6 \mathrm{~h}$ for 30 to $40 \mathrm{~min}$ from 12 to $96 \mathrm{~h}$ following the second $\mathrm{PGF}_{2 \alpha}$ treatment, with the help of a mature ram wearing an apron. Similarly, the non-return rates was determined by monitoring every $6 \mathrm{~h}$ for 30 to $40 \mathrm{~min}$ from 13 to 21 days after insemination, with the help of a mature ram wearing an apron (Olivera-Muzante et al., 2011). The non-returned ewes were checked for pregnancy by ultrasound 40 to 50 days after AI (Olivera-Muzante et al., 2011). The oestrus response (number of ewes showing oestrus/ number treated $\times 100$ ), non-return rate (number of ewes not returning to oestrus/ number inseminated $x$ 100), pregnancy rate (number of pregnant ewes/ number inseminated $\times 100$ ), lambing rate (number of lambing ewes/ number of pregnant ewes $\times 100$ ), multiple birth rates (number of ewes lambing twin or triplet/ total number of lambing ewes $\times 100$ ), lambing size (number of total lambs/ number of lambing ewes $\times 100$ ) and the female or male lamb rates (number of female or male lamb/ total number of lambs $\times 100$ ) were recorded (Türk et al., 2008). 


\section{Data analysis}

Excel (Microsoft Excel 2010) was used to record and calculate the frequency distribution of onset of oestrus, and SPSS (Version 20; IBM) was used for other data analysis. The gestation periods and lambing size were compared by one-way analysis of variance (ANOVA) followed by post hoc Tukey-HSD test. The other reproductive traits were compared by Chi-squared test. Data for gestation period and lambing size were presented as mean \pm S.E.M. and a value $p<0.05$ was considered significantly different.

\section{RESULTS}

\section{Onset of oestrus and oestrus response rates}

The frequency distribution of onset of oestrus in ewes following second $\mathrm{PGF}_{2 \alpha}$ treatment is shown in Fig. 1. The oestrus response rates was $100 \%$ (89/89) with the ewes coming into oestrus 28 to $76 \mathrm{~h}$ with a mean time of 54.33 $\pm 1.28 \mathrm{~h}$ after the second $\mathrm{PGF}_{2 \alpha}$ treatment. The highest percentages of ewes observed in oestrus between 51 to 60 h were $29.2 \%$ (26/89). Only $2.2 \%$ (2/89) of ewes showed onset of oestrus between 21 to $30 \mathrm{~h}$.

\section{Reproductive performances}

1) Non-return rates, pregnancy rates, and gestation period

Table 1 show the non-return and pregnancy rates. The

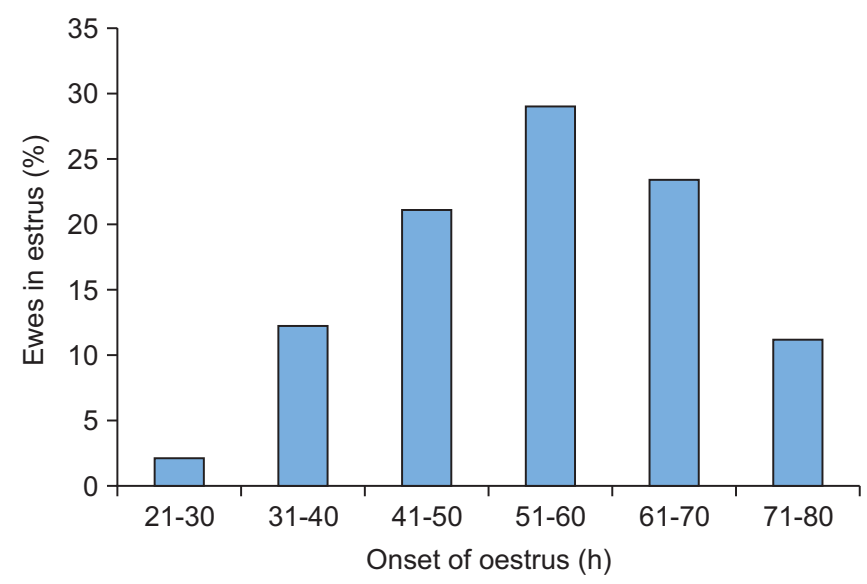

Fig. 1. Frequency distribution of onset of oestrus in ewes after second $\mathrm{PGF}_{2 \alpha}$ treatment. Selected non-pregnant ewes $(n=89)$ were treated with two doses of $0.4 \mathrm{~mL}(100 \mu \mathrm{g})$ intramuscular (im) prostaglandin $\mathrm{F}_{2 \alpha}\left(\mathrm{PGF}_{2 \alpha}\right)$ analogue (Cloprostenol, Ovuprost) 9 days apart for oestrus synchronization. The ewes were monitored every $6 \mathrm{~h}$ for 30 to $40 \mathrm{~min}$ from 12 to $96 \mathrm{~h}$ following the second $\mathrm{PGF}_{2 \alpha}$ treatment, with the help of a mature ram wearing an apron. non- return rate were higher in group D200 (56.5\%) than group S100 $(11.1 \%)(p<0.05)$. None of the ewes were pregnant in group S100, and the pregnancy rates among the remaining groups varied insignificantly. The mean gestation period was $152.8 \pm 0.5$ days and no difference was observed among the groups.

\section{2) Lambing performance}

The lambing rates of each group were $100 \%$ (Table 1). The differences in multiple birth rates and the number of lambing among the groups were insignificant. The multiple birth rate was highest in group D200 $(100 \%, 6 / 6)$ but differed insignificantly with group S200 $(75 \%, 3 / 4)$ and group D100 $(66.7 \%, 2 / 3)$. The single and twin lambing was highest in group D100 $(33.3 \%, 1 / 3)$ and group D200 $(83.3 \%, 5 / 6)$, respectively. The lambing size did not differ among the groups, however was highest in group D200 $(2.2 \pm 0.2)$ followed by group S200 $(1.8 \pm 0.3)$ and group D100 (1.7 \pm 0.3$)$. The male and female lambing rates differed insignificantly.

\section{DISCUSSION}

We evaluated the effects of the number of frozenthawed ram sperm and the number of inseminations on fertility in synchronized ewes under field conditions in Bangladesh. We observed 100\% estrous response and lambing rates. The overall reproductive performance was observed higher in the group inseminated twice with 200 $\times 10^{6}$ sperm; no ewes became pregnant in the group inseminated once with $100 \times 10^{6}$ sperm.

The success of AI depends on the efficacy of the oestrus synchronization (Gungor et al., 2007; Hashem et al., 2015), quality of frozen semen (Tekin, 2006) and timing of $\mathrm{AI}$ (Hashemi et al., 2006). We used $\mathrm{PGF}_{2 \alpha}$ as an oestrus synchronizing agent which is believed to be a cost-effective luteolytic agent (Davis et al., 1980; Light et al., 1994).

Despite its wide variation in oestrus response (up to $100 \%$ ) and onset of oestrus, (over a 4 day interval; Menchaca and Rubianes, 2004), the oestrus response rates in our study were in agreement with Öztürkler et al. (2003) and Zohara et al. (2014) who reported oestrous response $100 \%$ using Cloprostenol $75 \mu \mathrm{g}$ and $100 \mu \mathrm{g} /$ ewe in Bangladeshi and Tushin ewes. In contrast, Trounson et al. (1976) reported oestrus response rates of $84 \%$ and $80 \%$ in ewes using $100 \mu \mathrm{g}$ and $125 \mu \mathrm{g}$ cloprostenol, respectively. 
Table 1. Reproductive performances of ewes in different Al group

\begin{tabular}{|c|c|c|c|c|}
\hline \multirow{2}{*}{ Reproductive parameters } & \multicolumn{4}{|c|}{ Group } \\
\hline & D200 & S200 & D100 & $\mathrm{S} 100$ \\
\hline Number of ewes & 23 & 24 & 24 & 18 \\
\hline Non-return rates (\%) & $56.5^{\mathrm{a}}(13 / 23)$ & $41.7^{\mathrm{a}, \mathrm{b}}(10 / 24)$ & $25.0^{\mathrm{a}, \mathrm{b}}(6 / 24)$ & $11.1 \mathrm{~b}(2 / 18)$ \\
\hline Pregnancy rates (\%) & $26.1(6 / 23)$ & $16.7(4 / 24)$ & $12.5(3 / 24)$ & $0(0 / 18)$ \\
\hline \multicolumn{5}{|l|}{ Gestation period (days) } \\
\hline Single (mean \pm S.E.M.) & NA & 154.0 & 152.0 & NA \\
\hline Twin (mean \pm S.E.M.) & $153.2 \pm 0.4$ & $152.0 \pm 2.3$ & $153.5 \pm 0.5$ & NA \\
\hline Triplet (mean \pm S.E.M.) & 151.0 & NA & NA & NA \\
\hline Lambing rates $(\%)$ & $100(6 / 6)$ & $100(4 / 4)$ & $100(3 / 3)$ & NA \\
\hline Multiple birth rates (\%) & $100(6 / 6)$ & $75(3 / 4)$ & $66.7(2 / 3)$ & NA \\
\hline \multicolumn{5}{|l|}{ Number of lambs } \\
\hline Single (\%) & NA & $25(1 / 4)$ & $33.3(1 / 3)$ & NA \\
\hline Twin (\%) & $83.3(5 / 6)$ & $75(3 / 4)$ & $66.7(2 / 3)$ & NA \\
\hline Triplet (\%) & $16.7(1 / 6)$ & NA & NA & NA \\
\hline Lambing size (mean \pm S.E.M.) & $2.2 \pm 0.2$ & $1.8 \pm 0.3$ & $1.7 \pm 0.3$ & NA \\
\hline Female lamb rates (\%) & $46.2(6 / 13)$ & $57.1(4 / 7)$ & $40.0(2 / 5)$ & NA \\
\hline Male lamb rates (\%) & $53.8(7 / 13)$ & $42.9(3 / 7)$ & $60.0(3 / 5)$ & NA \\
\hline
\end{tabular}

Differences among values bearing different superscripts $(a, b)$ are statistically significant $(p<0.05)$.

NA: Not applicable.

Selected non-pregnant ewes $(n=89)$ were randomly assigned to 4 groups: D200 ( $n=23$; double Al with $200 \times 10^{6}$ sperm), S200 $(n=24 ;$ single Al with $200 \times 10^{6}$ sperm), D100 ( $n=24$; double Al with $100 \times 10^{6}$ sperm) and S100 $\left(n=18\right.$; single Al with $100 \times 10^{6}$ sperm). The insemination was performed 12 to $18 \mathrm{~h}$ after the onset of oestrus for single Al, or 10 to $12 \mathrm{~h}$ and 16 to $18 \mathrm{~h}$ after the onset of oestrus for double Al. Ewes which did not return to oestrus after 13 to 21 days post insemination were submitted to ultrasonography between 40 to 50 days for confirmation of pregnancy. Reproductive parameters such as oestrus response (number of ewes showing oestrus/number of treated ewes $\times 100$ ), non-return (number of ewes non-return to oestrus/number of inseminated ewes in each group $\times 100$ ), pregnancy rates (number of pregnant ewes/number of inseminated ewes in each group $\times 100$ ), lambing rates (number of lambing ewes/ number of pregnant ewes in each group $\times 100$ ), multiple birth rates (number of ewes lambing twin or triplet/ total number of lambing ewes in each group $\times 100$ ), lambing size (number of total lambs/ number of lambing ewes in each group $\times 100$ ) and the female or male lamb rates (number of female or male lamb/ total number of lambs in each group $\times 100$ ) were recorded. The reproductive traits were expressed as $\%$ except the gestation period and lambing size which were expressed as mean \pm S.E.M.

${ }^{*} p<0.05$ was compared among the groups.

Hashem et al. (2015) and Menchaca et al. (2004) reported oestrus response rates $78.57 \%$ with $5 \mathrm{mg}$ dinoprost tromethamine and 82.4 to $93.9 \%$ with $160 \mu$ g delprostenate in ewes. The mean time to onset of oestrus in our study was closer to Hashem et al. (2015), who reported $50.4 \pm$ $7.3 \mathrm{~h}$. The higher proportion of oestrus observed between 41 to $70 \mathrm{~h}$ was in agreement with Acritopoulou-Fourcroy et al. (1982), but differs with Menchaca et al. (2004) who reported between 25 to $48 \mathrm{~h}$.

Variation in oestrus response is due to differences in season, the presence of ram in the herd (Moeini et al., 2009), body condition and management system (Yadi et al., 2011), nutritional condition and latitude (Martinez$\mathrm{T}$ et al., 2011). The parity and breeds may also affect the oestrus response. A lower mean time of estrous than our result has been reported in the Corriedale breed both in nulliparous $(39.6 \pm 1.1 \mathrm{~h})$ and multiparous $(40.6 \pm 0.5$ h) ewes (Menchaca et al., 2004). The mean time to onset of oestrus could vary due to the follicular status of an individual ewe. A large healthy growing follicle at time of treatment will continue its development leading to oestrus and ovulation soon after $\mathrm{PGF}_{2 \alpha}$ administration. Similarly, while the largest follicle is in a regressing phase, a new follicle needs to emerge, and normally oestrus and ovulation will follow (Menchaca and Rubianes, 2004; Hashem et al., 2015).

The non-return rates depends upon the fertility of the ram. The non-return rates in our study ranged from 11.1 to $56.5 \%$. The highest non-return rate of $56.5 \%$ in group D200 was comparable with that of Kerton et al. (1984) who reported $56 \%$, and $31 \%$ after vaginal insemination. The variation in non-return rates could be due to the skill of the 
technician, difference in flock conditions, and observation of the oestrus behavioural signs (Andersen Berg and Aamdal, 1991). Non-return rates is also associated with insemination being conducted too early; deleterious effects often occur both before and after maternal recognition of pregnancy (Olivera-Muzante et al., 2011). The rams used as donors in this study were selected based on semen evaluation (Jha et al., 2018), not on breeding value. However, it is ideal to select rams for AI based on breeding value after natural mating, which is an important index of fertility.

The highest pregnancy rates $(26.1 \%)$ in this study was observed after double AI with $200 \times 10^{6}$ sperm. Rekha et al. (2016b) reported $20.8 \%$ pregnancy rate using frozen semen in Bangladesh ewes. However, the pregnancy rates in our study using double insemination with $100 \times 10^{6}$ sperm was comparable with Rekha et al. (2016b) who obtained $13.6 \%$. This difference might be due to the higher number of sperm per insemination and double AI. The pregnancy rates may vary with the type of semen used, insemination technique and stage of oestrus. In sheep the AI dose (number of motile sperm/ insemination) has been reported to range from 50 to $200 \times 10^{6}$ and inseminated using single or double doses ( 6 to $8 \mathrm{~h}$ apart) between 12 to $24 \mathrm{~h}$ after the onset of oestrus (D'Alessandro et al., 2001; Nordstoga et al., 2009; Paulenz et al., 2009). The pregnancy rates was $85 \%$ after $\mathrm{AI}$ with fresh semen in natural oestrus (Meinecke and Meinecke-Tillmann, 1986), 88.4\% with fresh semen inseminated into the cervix (Khalifa et al., 2008), 25 to $27.3 \%$ and 7.1 to $26.8 \%$ with chilled semen inseminated trans-cervical (Rekha et al., 2016a), $50.8 \%$ and $53.5 \%$ following vaginal and cervical insemination with chilled semen at $400 \times 10^{6}$ sperm in Sarda ewes (Branca et al., 1994), 60\% and 64\% following insemination with $100 \times 10^{6}$ sperm after vaginal and cervical insemination (Maxwell and Hewitt, 1986) and 59.3\% with frozen semen inseminated trans-cervical (Wulster-Radcliffe and Lewis, 2002). The lambing rates in our study were $100 \%$. In contrast, Tervit et al. (1984) reported lambing rates of about $69 \%$ and $64 \%$ following insemination with $225 \times$ $10^{6}$ sperm by cervical and vaginal insemination, respectively. The lambing rates and lambing size depends upon genetic potential, plane of nutritional, age, weight, and timing of AI (Downing and Scaramuzzi, 1991).

In conclusion, double AI with $200 \times 10^{6}$ sperm showed comparatively most practical for achieving high pregnancy rates and lambing performances in Bangladeshi ewes under field conditions. This study provides some preliminary and important results that suggest room for further research with a greater number of ewes. We also suggest that such further research is also needed in appropriate knowledge transfer leading to highest technology adoption rates, including methods for in-depth training of sheep farmers and appropriate dissemination of this technology which will result in enhanced fertility.

\section{CONFLICTS OF INTEREST}

No potential conflict of interest relevant to this article was reported.

\section{ACKNOWLEDGEMENTS}

The authors are grateful to the Bangladesh Academy of Science and United States Department of Agriculture (BAS-USDA; LS-02) for financial support and Department of Livestock Services (DLS) officers of Mymensingh district for continuous co-ordination with the sheep farmers. We are particularly grateful to Dr. W. R. Ward, Senior Fellow, Institute of Veterinary Science, University of Liverpool, United Kingdom for linguistic editing.

\section{AUTHOR CONTRIBUTIONS}

Conceptualization: Pankaj Kumar Jha, Farida Yeasmin Bari

Data curation, Software and Formal analysis: Pankaj Kumar Jha, A. K. M. Anisur Rahman

Methodology: Pankaj Kumar Jha, Farida Yeasmin Bari, Mohammad Rafiqul Islam Talukder, Md. Abdullah Al Mansur, Nazmun Naher

Investigation and validation: Farida Yeasmin Bari, Md. Golam Shahi Alam

Writing - original draft: Pankaj Kumar Jha

Writing - review and editing: Farida Yeasmin Bari, Md. Golam Shahi Alam, David C. Hall

\section{AUTHOR'S POSITION AND ORCID NO.}

\author{
PK Jha, Ph.D Student, \\ https://orcid.org/0000-0001-6374-9201 \\ MGS Alam, Professor, \\ https://orcid.org/0000-0002-7605-5513 \\ MAA Mansur, M.S Student,
}


https://orcid.org/0000-0003-4754-3427

MRI Talukder, Ph.D Student,

https://orcid.org/0000-0003-3693-6807

N Naher, M.S Student,

https://orcid.org/0000-0002-9583-458X

AKMA Rahman, Professor,

https://orcid.org/0000-0001-9660-4949

DC Hall, Professor,

https://orcid.org/0000-0002-6622-1848

FY Bari, Professor,

https://orcid.org/0000-0003-1358-460X

\section{REFERENCES}

Acritopoulou-Fourcroy S, Pappas V, Peclaris G, Zervas N, Skoufis V. 1982. Synchronization of oestrus in ewes with Provera sponges/PMSG, prostaglandin F $2 \alpha$ or the prostaglandin analogue, ICI 80996, and fertility following natural mating or artificial insemination. Reprod. Nutr. Dévelop. 22:345-354.

Andersen Berg K and Aamdal J. 1991. Artificial insemination with frozen semen in ewes at different times of the breeding season. Reprod. Domest. Anim. 26:27-30.

Anel L, Alvarez M, Martinez-Pastor F, Garcia-Macias V, Anel E, de Paz P. 2006. Improvement strategies in ovine artificial insemination. Reprod. Domest. Anim. 41 Suppl 2:30-42.

Anel L, de Paz P, Alvarez M, Chamorro CA, Boixo JC, Manso A, González M, Kaabi M, Anel E. 2003. Field and in vitro assay of three methods for freezing ram semen. Theriogenology 60:1293-1308.

Azizunnesa, Zohara BF, Bari F, Alam MGS. 2014. Effects of proportion of egg yolk and preservation time on chilled semen from indigenous rams. GSTF J. Vet. Sci. 1:18-26.

Bhuiyan AKFH. 2006. Livestock genetic resources in Bangladesh: preservation and management. International conference on livestock services, Chinese Academy of Agricultural Science (CAAS), Beijing, China, pp. 16-20.

Branca A, Cappai P, Dattene M, Gallus M, Ledda S, Loi P, Naitana S. 1994. A simplified method of artificial insemination for ewe lambs. In: Abstraacts of the XI Congresso Nazinale Societa Italiana Di Patologia e Di Allevamento Degli Ovini e Di Caprini. Perugia, Italy. pp. 317-318.

D'Alessandro AG, Martemucci AG, Colonna MA, Bellitti A. 2001. Post-thaw survival of ram spermatozoa and fertility after insemination as affected by prefreezing sperm concentration and extender composition. Theriogenology 55:11591170.

Davis A, Fleet I, Harrison F, Walker FM. 1980. Pulmonary metabolism of prostaglandin F2a in the conscious non-pregnant ewe and sow. J. Physiol. 301(Suppl), 86.

Downing JA and Scaramuzzi RJ. 1991. Nutrient effects on ovulation rate, ovarian function and the secretion of gonadotrophic and metabolic hormones in sheep. J. Reprod. Fertil.
Suppl. 43:209-227.

Güngör Ö, Cenesiz M, Pancarci SM, Yıldız S, Kaya M, Kaçar C, Özyurtlu N, Gürbulak K. 2007. Effects of different intravaginal progesterone releasing devices on estrous synchronization and LH surge in fat-tailed ewes during non-breeding season. Med. Weter. 63:1316-1319.

Hashem NM, El-Zarkouny SZ, Taha TA, Abo-Elezz ZR. 2015. Oestrous response and characterization of the ovulatory wave following oestrous synchronization using PGF2 $\alpha$ alone or combined with GnRH in ewes. Small Rumin. Res. 129:8487.

Hashemi M, Safdarian M, Kafi M. 2006. Estrous response to synchronization of estrus using different progesterone treatments outside the natural breeding season in ewes. Small Rumin. Res. 65:279-283.

Jha PK, Alam M, Al-Mansur MA, Islam M, Bari F. 2018. Selection of breeding rams by evaluating semen quality. J. Appl. Anim. Sci. 11:9-20.

Jha PK, Alam MGS, Mansur AAL, Naher N, Islam T, Bhuiyan MU, Bari FY. 2019. Cryopreservation of Bangladeshi ram semen using different diluents and manual freezing techniques. Cryobiology 89:35-41.

Kerton D, McPhee S, Davis I, White M, Banfield J, Cahill L. 1984. A comparison of insemination techniques in Corriedale ewes. Proceedings of the Australian Society of Animal Production. 15, pp.701.

Khalifa TA, Lymberopoulos AG, El-Saidy BE. 2008. Testing usability of butylated hydroxytoluene in conservation of goat semen. Reprod. Domest. Anim. 43:525-530.

Light JE, Silvia WJ, Reid RC 2nd. 1994. Luteolytic effect of prostaglandin F2 alpha and two metabolites in ewes. J. Anim. Sci. 72:2718-2721.

Martinez-Tinajero JJ, Ruiz-Herluver I, Montanez-Valdez OD, Martinez-Priego G, Velasco-Zebadua ME, Izaguirre F. 2011. Reproductive performance in Dorper ewes synchronized at estrus during non breeding season in tropical conditions. J. Anim. Vet. Adv. 10:221-223.

Maxwell WM, Landers AJ, Evans G. 1995. Survival and fertility of ram spermatozoa frozen in pellets, straws and minitubes. Theriogenology 43:1201-1210.

Maxwell WMC and Hewitt LJ. 1986. A comparison of vaginal, cervical and intrauterine insemination of sheep. J. Agric. Sci. 106:191-193.

Meinecke B and Meinecke-Tillmann S. 1986. [Fertilization results in superovulated ewes and goats after transmuralintrauterine insemination controlled by laparoscopy]. Tierarztl. Prax. 14:35-41. German.

Menchaca A, Miller V, Gil J, Pinczak A, Laca M, Rubianes E. 2004. Prostaglandin F2alpha treatment associated with timed artificial insemination in ewes. Reprod. Domest. Anim. 39:352-355

Menchaca A and Rubianes E. 2004. New treatments associated with timed artificial insemination in small ruminants. Reprod. Fertil. Dev. 16:403-413.

Moeini MM, Alipour F, Moghadam A. 2009. The effect of hu- 
man chorionic gonadotropin on the reproduction performance in Lory sheep synchronized with different doses of pregnant mare serum gonadotrophin outside the breeding season. Asian J. Anim. Vet. Adv. 4:9-15.

Nordstoga AB, Söderquist L, Ådnøy T, Paulenz H. 2009. Effect of different packages and freezing/thawing protocols on fertility of ram semen. Reprod. Domest. Anim. 44:527-531.

Olivera-Muzante J, Fierro S, López V, Gil J. 2011. Comparison of prostaglandin- and progesterone-based protocols for timed artificial insemination in sheep. Theriogenology 75:12321238.

Öztürkler Y, Çolak A, Baykal A, Guven B. 2003. Combined effect of a prostaglandin analogue and a progestagen treatment for 5 days on oestrus synchronisation in Tushin ewes. Indian Vet. J. 80:917-920.

Paulenz H, Adnøy T, Fossen OH, Söderquist L. 2009. Effect on field fertility of addition of gelatine, different dilution rates and storage times of cooled ram semen after vaginal insemination. Reprod. Domest. Anim. 45:706-710.

Paulenz H, Adnøy T, Fossen OH, Söderquist L, Berg KA. 2002. Effect of deposition site and sperm number on the fertility of sheep inseminated with liquid semen. Vet. Rec. 150:299302.

Rekha A, Zohara BF, Bari F, Alam MGS. 2016a. Comparison of commercial Triladyl extender with a tris-fructose-egg-yolk extender on the quality of frozen semen and pregnancy rate after transcervical AI in Bangladeshi indigenous sheep (Ovis aries). Small Rumin. Res. 134:39-43.

Rekha A, Zohara BF, Bari FY, Alam MGS. 2016b. Comparisons of commercial Triladyl and locally manufactured extenders for the chilling of semen and their effects on pregnancy rates after transcervical AI in Bangladeshi Indigenous (Ovis aries) sheep. Anim. Reprod. 13:735-742.

Roy PK, Zohara BF, Nesa A, Paul AK, Bhuiyan MMU, Bari FY.
2014. Oestrus synchronization with Ovuprost ${ }^{\circledR}$ and Prostenol ${ }^{\circledR}$ in the indigenous ewes of Bangladesh. J. Emb. Trans. 29:149-155.

Tekin N, Uysal O, Akçay E, Yavaş İ. 2006. Effects of different taurine doses and freezing rate on freezing of row semen. Ank. Üniv. Vet. Fak. Derg. 53:179-184.

Tervit H, Goold P, James R. 1984. The insemination of sheep with fresh or frozen semen. In: Abstracts of the proceedings of the New Zealand Society of Animal Production. pp. 11-13.

Trounson AO, Willadsen SM, Moor RM. 1976. Effect of prostaglandin analogue Cloprostenol on oestrus, ovulation and embryonic viability in sheep. J. Agric. Sci. 86:609-611.

Türk G, Gür S, Sönmez M, Bozkurt T, Aksu EH, Aksoy H. 2008. Effect of exogenous $\mathrm{GnRH}$ at the time of artificial insemination on reproductive performance of Awassi ewes synchronized with progestagen-PMSG-PGF2alpha combination. Reprod. Domest. Anim. 43:308-313.

Turner HN. 1983. Origins of the CSIRO Booroola. Wool Technol. Sheep Breed. 31:10-13.

Wulster-Radcliffe MC and Lewis GS. 2002. Development of a new transcervical artificial insemination method for sheep: effects of a new transcervical artificial insemination catheter and traversing the cervix on semen quality and fertility. Theriogenology 58:1361-1371.

Yadi J, Moghaddam MF, Khalajzadeh S, Solati AA. 2011. Comparison of estrus synchronization by PGF2 $\alpha$, CIDR and sponge with PMSG in Kalkuhi ewes on early anestrous season. In: Abstracts of the International Conference on Asia Agriculture and Animal. Singapoore. pp. 61-65.

Zohara BF, Azizunnesa A, Faruk I, Alam MGS, Bari FY. 2014. Comparison of estrus synchronization by PGF2 $\alpha$ and progestagen sponge with PMSG in indigenous ewes in Bangladesh. GSTF J. Vet. Sci. 1:27-37. 